\title{
Investigation on Selecting Optimal Wind Turbines in the Capacity Factor Point of View
}

\author{
Woo, Jae-kyoon* Kim, Byeong-min** Paek, In-su*** Yoo, Neung-soo*** Nam, Yoon-su*** \\ *Dept. of Power Plant, Dohwa Engeering CO.,LTD(jkwoo@dohwa.ac.kr), \\ **Dept. of Mechanical and Mechatronics Engineering, Graduate School, Kangwon National \\ University(rhapsodist@kangwon.ac.kr), \\ ***Dept. of Mechanical and Mechatronics Engineering, Kangwon National University, Assistant \\ professor, Ph.D(paek@kangwon.ac.kr), \\ ***Dept. of Mechanical and Mechatronics Engineering, Kangwon National University, Professor, \\ Ph.D(yoonesoo@kangwon.ac.kr), \\ ***Dept. of Mechanical and Mechatronics Engineering, Kangwon National University, Professor, \\ Ph.D(nys@kangwon.ac.kr)
}

\section{이용률 관점에서의 최적 풍력발전기 선정에 대한 연구}

\author{
우재균*, 김병민**, 백인수***, 유능수***, 남윤수*** \\ *(주)도화 엔지니어링 발전플랜트부(jkwoo@dohwa.co.kr), \\ **강원대학교 대학원 기계메카트로닉스공학과(rhapsodist@kangwon.ac.kr), \\ ***강원대학교 기계메카트로닉스공학과 조교수, 공학박사(paek@kangwon.ac.kr), \\ ***강원대학교 기계메카트로닉스공학과 정교수, 공학박사(yoonesoo@kangwon.ac.kr), \\ ***강원대학교 기계메카트로닉스공학과 정교수, 공학박사(nys@kangwon.ac.kr)
}

\begin{abstract}
Selecting optimal wind turbine generators for wind farm sites in the capacity factor point of view is performed in this study. A program to determine the best wind turbine generator for the maximum capacity factor for a site was developed. The program uses both the wind characteristics of the site of interest and the power curves of the wind turbines. The program developed was applied to find out optimal wind turbine generators of three different sites in complex terrain and successfully yielded the best site dependent wind turbine generators. It was also used to determine the best wind turbine generator of the wind farm currently operating in Korea and proved its usefulness. The program and methodology developed in this study considered to be very useful at the initial design stage of the wind farm to determine the best wind turbine generators for the site of interest.
\end{abstract}

Keywords : Wind Farm, optimal Wind Turbine, Power Curve, Capacity Factor

투고일자 : 2011년 6월 22일, 심사일자 : 2011년 6월 25일, 게재확정일자 : 2011년 10월 10일

교신저자 : 백인수(paek@kangwon.ac.kr) 


\section{Introduction}

Since modern wind turbines came out, the wind turbine generators and wind farms have become larger and larger and so has been the budget for their construction. Because building a wind farm requires great amount of budget, interests on the efficiencies of the wind farm and how to maximize them have become very important issue in wind industry [1]. In order to achieve a high efficiency from a wind farm, one very important thing is to install wind turbine generators that are optimal for the particular site and wind characteristics [2,3].

To select optimal wind turbine generators for a wind farm, economic evaluation should be considered. Accurate economic evaluation requires comprehensive investigations on all the expenditures for construction and maintenance of a wind farm during the lifetime of wind turbine generators. Therefore, it is very difficult to have an accurate economic evaluation at the initial design stage of a wind farm. Also another thing to make the accurate economic evaluation difficult is that it depends on the time when the evaluation is made because the expenditure for construction and maintenance of a wind farm largely varies with time. Therefore for a rough estimation of proper wind turbines for a particular wind farm site at the initial design stage, the efficiency of the wind farm known as a Capacity Factor (CF) may be an alternative to be used as a criterion [4].

$\mathrm{CF}$ represents how well wind turbine generators produce power compared to their rated powers. Mathematically, it is defined as a ratio of the annual energy production (AEP) of a wind farm to the total capacity of the wind farm multiplied by 8,760 hours. Therefore, in order to calculate the CF of a wind farm, it is essential to know the AEP of the wind farm.

So far, when a validation study is carried out for a future wind farm site, wind farm design programs have been mainly used. Wind farm design programs provide tools for finding optimal wind farm layouts and yield the AEP and CF when particular wind turbine generators are selected by users. They don't, however, provide any tools to determine proper wind turbine generators for the wind farm site of interest. Without such tools, it is very time consuming and difficult job to select proper wind turbines for the particular site.

Therefore the objective of this paper is to develop a method to automatically determine proper wind turbines for particular sites in the perspective of the $\mathrm{CF}$ of the wind farm site. Although, the economic evaluation is not included in the method, this is considered very useful at the design stage of a wind farm.

\section{Methodology}

\subsection{Wind Resource}

To determine proper wind turbines for a region of interest, it is necessary to know the wind characteristics of the whole region. This can be done using commercial software for wind resource estimation.

The Weibull Probability Distribution (WPD) function that represents a wind characteristic of a site is mathematically defined by [3] 


$$
f(V)=\frac{k}{C}\left(\frac{V}{C}\right)^{k-1} \exp \left[-\left(\frac{V}{C}\right)^{k}\right]
$$

where $C$ is the scale factor in $\mathrm{m} / \mathrm{s}$, and $k$ is the shape factor.

\subsection{Power Curve}

The power curve data of wind turbine generators commercially available can be found as a form of text file. In the text file, the power of the wind turbine in $\mathrm{kW}$ is listed with respect to the wind speed. Table 1 shows an example of such power curve data. The lowest and highest wind speeds in the table that can generate electricity are called the cut-in and cut-out wind speeds, respectively.

Table 1. Example of power curve data of a wind turbine

\begin{tabular}{c|c||c|c}
\hline $\begin{array}{c}\text { Wind Speed } \\
(\mathrm{m} / \mathrm{s})\end{array}$ & $\begin{array}{c}\text { Power } \\
(\mathrm{kW})\end{array}$ & $\begin{array}{c}\text { Wind Speed } \\
(\mathrm{m} / \mathrm{s})\end{array}$ & $\begin{array}{c}\text { Power } \\
(\mathrm{kW})\end{array}$ \\
\hline \hline 1 & 0 & 14 & 2,000 \\
\hline 2 & 0 & 15 & 2,000 \\
\hline 3 & 0 & 16 & 2,000 \\
\hline 4 & 88 & 17 & 2,000 \\
\hline 5 & 204 & 18 & 2,000 \\
\hline 6 & 371 & 19 & 2,000 \\
\hline 7 & 602 & 20 & 2,000 \\
\hline 8 & 990 & 21 & 2,000 \\
\hline 9 & 1,229 & 22 & 2,000 \\
\hline 10 & 1,555 & 23 & 2,000 \\
\hline 11 & 1,835 & 24 & 2,000 \\
\hline 12 & 1,967 & 25 & 2,000 \\
\hline 13 & 1,967 & & \\
\hline
\end{tabular}

\subsection{AEP and $\mathrm{CF}$}

Using the WPD function and the power curves of the wind turbines described in Secs. 2.1 and 2.2, the AEP and the CF can be estimated. The AEP is mathematically defined as [5]

$$
A E P=\sum[P(V) \times f(V) \times 8760]
$$

where, $A E P$ is the annual energy production in kWh, $P(V)$ is the power production for wind speeds in $\mathrm{kW}, f(V)$ is the frequency of occurrence of wind speed.

As described in Introduction, the $C F$ is expressed by [5]

$$
C F(\%)=\frac{A E P}{P_{r} \times 8760} \times 100
$$

where $P_{r}$ is the rated power of wind turbines in $\mathrm{kW}$.

\subsection{Computer Code}

A program was developed using Matlab to find out wind turbine generators that yield the highest capacity factor at each site (refer to Fig. 1) of a region of interest. Figure 2 shows a flow chart of the program developed for this study. As explained in the previous sections, the wind resource data are obtained from a commercial wind resource prediction program[6-8]. In this study, WAsP [9.10] was used. The Weibull parameters $C$ and $k$ are then extracted from the wind resources data for the whole region of interests and used as one of the inputs in the optimization program. For all the wind turbine generators, the CF's are estimated using the Weibull parameters and power curve data locations by locations over the entire region and compared. Finally, the best wind turbine generator yielding the highest $\mathrm{CF}$ at each location (grid point) is determined and displayed. 


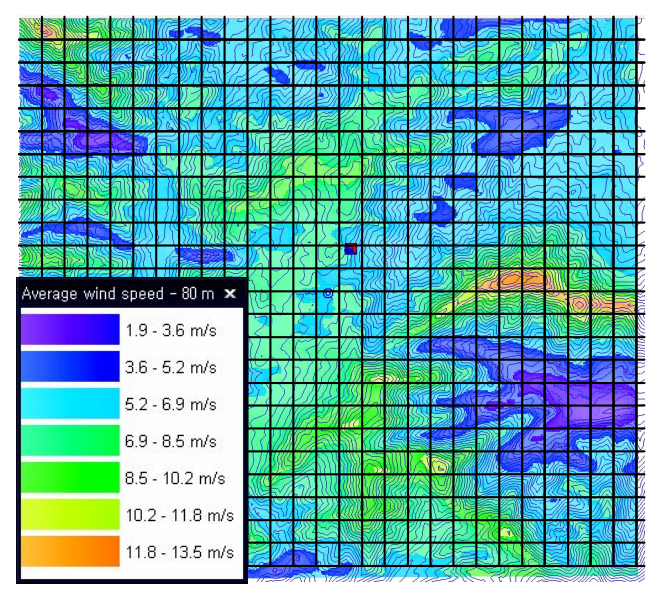

Fig 1. Wind resource map of a region

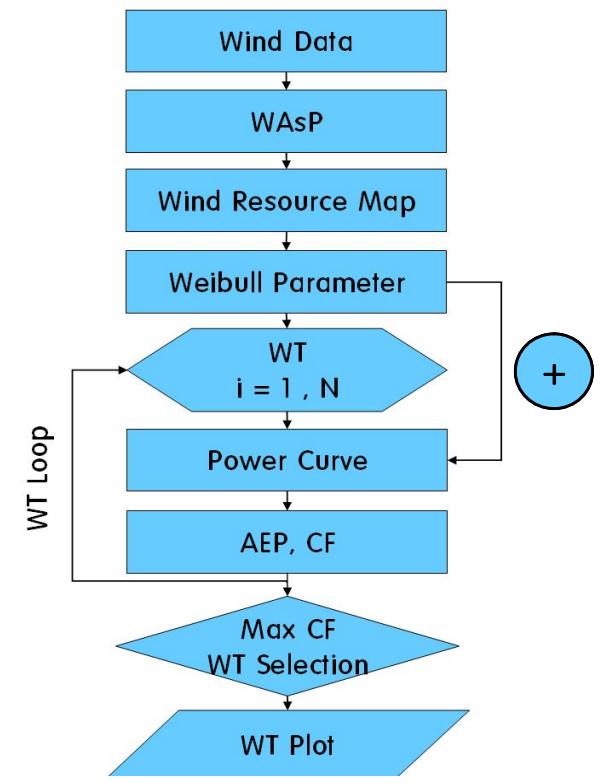

Fig 2. Flow chart of the optimization program

\section{Analysis and Results}

The simulation program based on the methodology described in Section 2 was applied to find out proper wind turbines for three different regions, $\mathrm{A}, \mathrm{B}$ and $\mathrm{C}$, and the results are shown in Fig. 3. All the three sites are mountainous as shown in the figure. The highest and lowest altitudes of the sites are listed in Table 2.
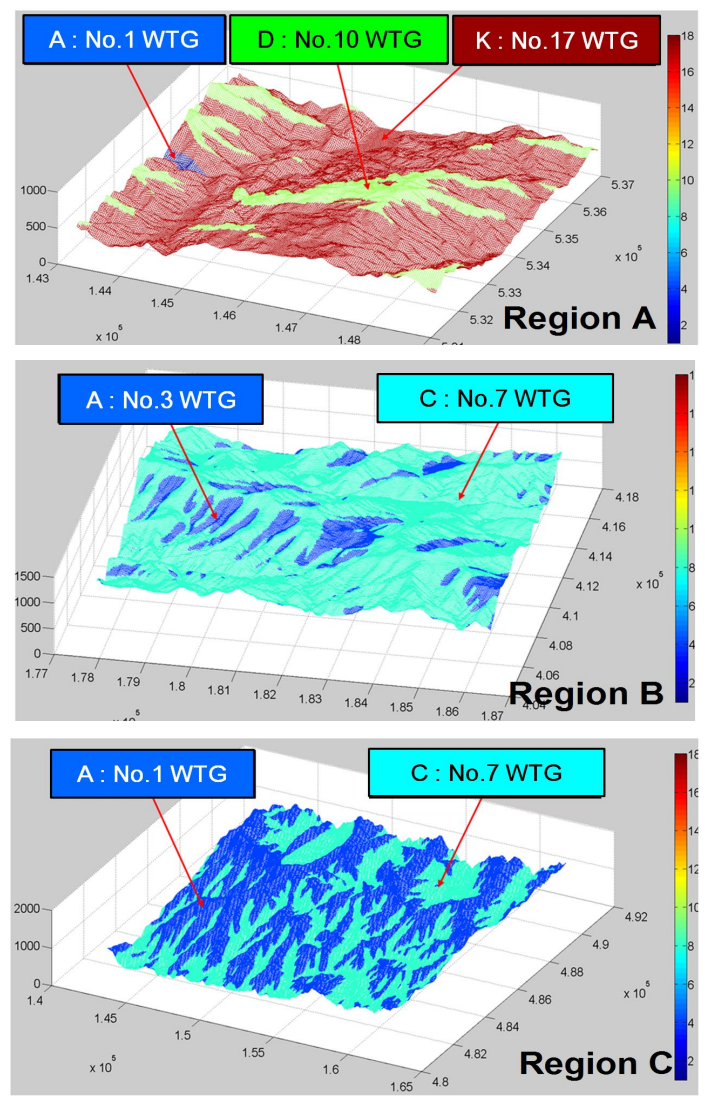

Fig 3. Map of optimal wind turbines for regions A, B and C

Table 2. Highest and lowest altitudes of regions A, B, and C

\begin{tabular}{l|c|c}
\hline & Highest altitude(m) & Lowest altitude(m) \\
\hline \hline Site A & 925 & 175 \\
\hline Site B & 823 & 225 \\
\hline Site C & 1,395 & 499 \\
\hline
\end{tabular}

In this study, a total of eighteen wind turbines from eleven different wind turbine manufacturers were considered. All of them have the same hub height, $80 \mathrm{~m}$. The wind turbines have various rated powers between 1.5 MW and 2.75 MW. The total 
wind turbines analyzed are listed on Table 3.

Table 3. List of wind turbines considered in the optimization

\begin{tabular}{|c|c|c|c|c|}
\hline No. & $\underset{\text { rer }}{\text { Manufactu }}$ & $\begin{array}{c}\text { Rated } \\
\text { Power } \\
(\mathrm{kW})\end{array}$ & $\begin{array}{c}\text { Rotor } \\
\text { Diameter } \\
(\mathrm{m})\end{array}$ & $\begin{array}{l}\text { Cut-in } \\
\text { Speed } \\
(\mathrm{m} / \mathrm{s})\end{array}$ \\
\hline 1 & \multirow{3}{*}{ A } & 1,800 & \multirow{3}{*}{90.0} & \multirow{3}{*}{4.0} \\
\hline 2 & & 2,000 & & \\
\hline 3 & & 3,000 & & \\
\hline 4 & B & 2,000 & 82.0 & 3.0 \\
\hline 5 & \multirow{3}{*}{ C } & 1,500 & 80.0 & 4.0 \\
\hline 6 & & 2,000 & 87.0 & 4.0 \\
\hline 7 & & 2,500 & 90.0 & 4.0 \\
\hline 8 & \multirow{3}{*}{ D } & 1,500 & 77.0 & \multirow{2}{*}{3.5} \\
\hline 9 & & 1,500 & 82.5 & \\
\hline 10 & & 2,500 & 88.0 & 4.0 \\
\hline 11 & $\mathrm{E}$ & 2,500 & 90.0 & 4.0 \\
\hline 12 & $\mathrm{~F}$ & 2,750 & 92.0 & 4.0 \\
\hline 13 & G & 2,000 & 84.0 & 4.0 \\
\hline 14 & $\mathrm{H}$ & 2,500 & 80.0 & 4.0 \\
\hline 15 & I & 2,500 & 80.0 & 4.0 \\
\hline 16 & $\mathrm{~J}$ & 2,000 & 80.0 & 3.5 \\
\hline 17 & \multirow{2}{*}{ K } & 2,300 & 92.6 & \multirow{2}{*}{4.0} \\
\hline 18 & & 2,300 & 82.4 & \\
\hline
\end{tabular}

The simulation results for the three regions are presented in Fig. 3. As shown in the figure, a few various wind turbines were selected for different sites. For region A, three different wind turbines were found to be the best for the $\mathrm{CF}$ for different locations. They were the No.1 wind turbine of company A (Refer to Table 3), No.10 wind turbine of company $\mathrm{D}$, and No.17 wind turbine of company K. For region B, the No.3 and No.7 wind turbines of companies $\mathrm{A}$ and $\mathrm{C}$ were the best, and the No.1 and No.7 wind turbines of companies $\mathrm{A}$ and $\mathrm{C}$ yielded the best $\mathrm{CF}$ for region $\mathrm{C}$.

\section{Application}

To prove the usability of the optimization program developed, it was applied to find out the best wind turbine for an existing wind farm in Korea. As shown in Fig. 4, the wind farm is located in a mountainous area, and has a total of 49 wind turbine generators. The total capacity of the wind farm is $98 \mathrm{MW}$. The wind turbines already installed in the wind farm are the No.2 wind turbines of company A having a hub height of $60 \mathrm{~m}$.

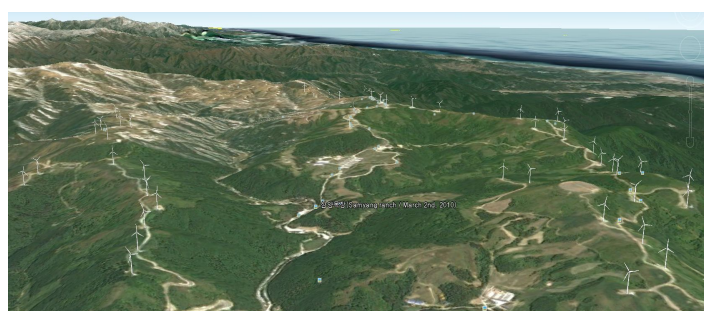

Fig 4. Satellite photo of the wind farm analyzed

In order to find out the wind resource of the wind farm region, the wind data obtained from a nearby AWS were used as an input to the Wind Atlas Analysis and Application Program (WAsP). WAsP is a PC program that is used extensively to estimate wind energy resources.

The AWS is about $2.6 \mathrm{~km}$ away from the closest wind turbine in the wind farm and $9.2 \mathrm{~km}$ away from the farthest. Then the A and $\mathrm{k}$ parameters of the region including all the wind farm locations were obtained. The measurement period of the data used was from Jan. 12009 to Dec. 312009.

The simulation results are presented in Fig. 5. As can be seen from the figure, the No.1 wind turbine of company A was found to be the best for most spots in the region. For some portion of the region, the No.17 wind turbine of company $\mathrm{K}$ was predicted to be the best. 
To validate the result, the capacity factors of the wind farm predicted using WAsP before and after the optimization were compared each other. The predictions were also compared with the measured $\mathrm{CF}$ of the wind farm [11]. Table 4 shows the results. First of all, before optimization, the WAsP prediction of the $\mathrm{CF}$ of the wind farm is very close to the measured $\mathrm{CF}$. This proves that the WAsP can be used to predict the $\mathrm{CF}$ of the wind farm. Also as expected, for the predicted CF's before and after optimization, the predicted $\mathrm{CF}$ after optimization was 1.1\% higher than that before optimization. This means that if the wind farm had chosen the No.1 wind turbine of company A, its efficiency would have been slightly higher than that of the current wind farm. This can lead to higher economic efficiency of the wind farm.

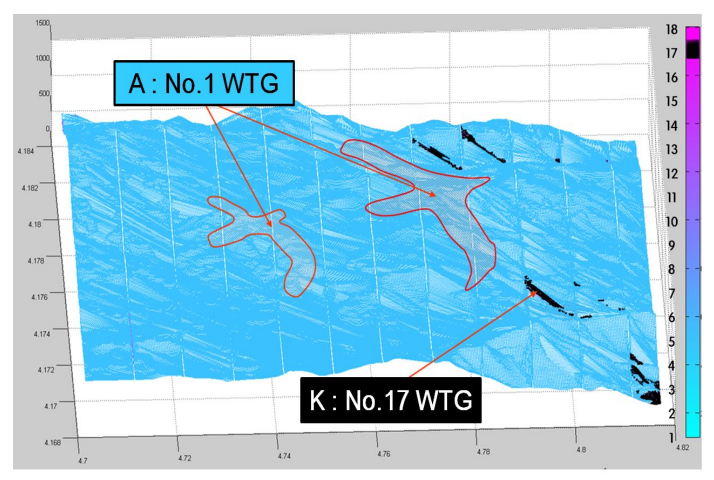

Fig 5. Map of proper wind turbines for the wind farm region.

Table 4. Measured vs. predicted CF of the wind farm before and after optimization.

\begin{tabular}{c|c|c|c}
\hline & Measured & $\begin{array}{c}\text { Predicted } \\
\text { (Before } \\
\text { Optimization) }\end{array}$ & $\begin{array}{c}\text { Predicted } \\
\text { (After } \\
\text { Optimization) }\end{array}$ \\
\hline \hline $\begin{array}{c}\text { Capacity } \\
\text { factor(\%) }\end{array}$ & 25.1 & 27.0 & 29.3 \\
\hline
\end{tabular}

\section{Conclusion}

A program to determine a proper wind turbine generator for the maximum $\mathrm{CF}$ at a site has been developed. The program uses both the wind characteristics of the site of interest and the power curve of wind turbine generators. It was applied to three different regions in complex terrain and yielded site-dependent proper wind turbine generators. For a validation, the program was applied to find out proper wind turbine generators of the wind farm currently operated in Korea. It successfully determined the wind turbine generators which could yield the $\mathrm{CF}$ which is about $1.1 \%$ higher than the $\mathrm{CF}$ of the current wind farm. The program and methodology developed in this study considered to be very useful at the initial design stage of the wind farm to determine proper wind turbine generators for the site of interest.

\section{Acknowledgement}

This work was supported by the New \& Renewable Energy of the Korea Institute of Energy Technology Evaluation and Planning (KETEP) grant funded by the Korea government Ministry of Knowledge Economy (No. 20093 021020030).

\section{References}

1. M.S. Jang, H.J. Bang, "The Current Status and the Prospects of Wind Energy", Jounal of the Environmental Sciences, Vol.18, No.8, pp.933-940. 2009.

2. T. Wizelius, "Developing Wind Power Projects”, EARTHSCAN, pp.47-59. 2006. 
3. Riso National Laboratory, Roskilde, Denmark, "European Wind Atlas", The Commission of the European Communities Directorate-General for Science, Research and Development, 1989.

4. Renewable Energy Research Laboratory, "Wind Power : Capacity Factor and Intermittency", University of Massachusetts at Amherst, 2003.

5. K. N. Ko and J.C Huh-I. Ushiyama, "Introduction to Wind Energy Engineering", Munundang, 2002.

6. K. Y. Yoon, I. Paek and N.S. Yoo, Wind Speed Prediction using WAsP for Complex Terrain, Proc. of the 2008 autumn Conf. of Korea Wind Energy Assoc., 2008.

7. Y. S.Hwang, I. Paek, K. Y. Yoon, W. S. Lee, N.S. Yoo and Y.S. Nam, "Application of wind data from automated weather stations to wind resources estimation in Korea," accepted for publication in Journal of Mechanical Science and Technology, 2010.

8. J. S. Bae, M.S. Jang, Y.C. Ju, J.E Yoon and N. H. Kyung, "Wind Resource Assessment of Antarctic King Sejong Station", Journal of the Korean Solar Energy Society, Vol.25, No.3, pp.53-60, 2005.

9. Risoe Laboratory online help page, http://www.wasp.dk/Support/FAQ/Web Help/Wasp9.htm\#RoughnessLength.htm.

10. "WAsP Manual : Wind Analysis and application Program (WAsP ): User Guide”, Risoe Laboratory, Roskilde, Denmark, ISBN 97-550-178,1993.

11. S.S. Ju, "CDM Monitoring Report 2009", Gangwon Wind Park Project (CDM Registration Reference Number 0222), 2010. 